\title{
Spatial and Temporal Effects of Decommissioning a Zinc Smelter on the Sediment Quality of an Estuary System: Sepetiba Bay, Rio de Janeiro, Brazil
}

\author{
Rodrigo A. Gonçalves, ${ }^{a}$ Douglas F. Oliveira, ${ }^{a}$ Carlos Eduardo Rezende, ${ }^{b}$ \\ Phelipe Almeida, ${ }^{c}$ Luiz D. de Lacerda, ${ }^{d}$ Bernardo A. P. da Gama ${ }^{e}$ and \\ José Marcus Godoy ${ }^{\circledR *}$ *a \\ ${ }^{a}$ Departamento de Química, Pontifícia Universidade Católica do Rio de Janeiro, \\ Rua Marques de São Vicente, 225, Gávea, 22451-900 Rio de Janeiro-RJ, Brazil \\ ${ }^{b}$ Laboratório de Ciências Ambientais, Centro de Biociências e Biotecnologia, \\ Universidade Estadual do Norte Fluminense, Av. Alberto Lamego, 2000, Parque Califórnia, \\ 28013-602 Campos dos Goytacazes-RJ, Brazil \\ 'PH-Mar Consultoria Ambiental, Rua Almirante Cochrane, 33, Tijuca, \\ 20550-040 Rio de Janeiro-RJ, Brazil \\ ${ }^{d}$ Laboratório de Ciências do Mar (LABOMAR), Universidade Federal do Ceará, \\ Avenida da Abolição, 3207, Meireles, 60165-081 Fortaleza-CE, Brazil \\ ${ }^{e}$ Departamento de Biologia Marinha, Universidade Federal Fluminense, \\ Outeiro de São João Batista s/n, Niterói, 24001-970 Rio de Janeiro-RJ, Brazil

\begin{abstract}
Sepetiba Bay, Rio de Janeiro, Brazil, was home to a zinc smelter until its shutdown in 1998, and during 2011 the remains of the smelter were decommissioned. This study investigates the impact of decommissioning on metal concentrations in the bottom sediments of the bay. In addition to $\mathrm{Zn}$ and $\mathrm{Cd}, \mathrm{Cr}, \mathrm{Cu}, \mathrm{Ni}$ and $\mathrm{Pb}$ are also quantified. The results show that over these 15 years, $\mathrm{Cd}$ and Zn concentrations have decreased by 100 and $70 \%$, respectively. Temporal effects are also studied by applying five dated ${ }^{210} \mathrm{~Pb}$ cores, which are validated using the $\mathrm{Zn}$ and $\mathrm{Cd}$ profiles. The observed decrease in the $\mathrm{Zn}$ concentration in oysters is correlated with its reduction in the sediment. It was possible to verify the impact of $\mathrm{Cr}, \mathrm{Cu}, \mathrm{Ni}$ and $\mathrm{Pb}$ on the sediment quality due to the remaining metallurgical industries in the Sepetiba Bay basin.
\end{abstract}

Keywords: zinc, cadmium, heavy metals, Sepetiba Bay, sediments, ${ }^{210} \mathrm{~Pb}$ dating

\section{Introduction}

The Mercantil and Industrial Ingá Company was a zinc ore processing plant located on Madeira Island in Sepetiba Bay, Rio de Janeiro, that was founded in 1962 and ceased its activities in the late 1990s, when the company went bankrupt. ${ }^{1}$ The zinc production process was based on calamine $\left(\mathrm{Zn}_{2} \mathrm{SiO}_{3}(\mathrm{OH})_{2}\right)$ and willemite $\left(\mathrm{Zn}_{2} \mathrm{SiO}_{4}\right)$, extracted in the state of Minas Gerais, ${ }^{2,3}$ and transported to Rio de Janeiro State. The industrial process was based on acid leaching with sulfuric acid and permanganate and on metallic zinc and cadmium production by electrolysis. ${ }^{4}$

Initially, liquid effluents were discharged directly into

*e-mail: jmgodoy@puc-rio.br
Sepetiba Bay in a mangrove area near Saco do Engenho. The solid waste was accumulated in the company's courtyard and formed mountains of open-air toxic tailings. In 1984, the company built a clay dike on the perimeter of the waste disposal area, and to contain solid and liquid wastes, the company installed water accumulation tanks, as well as a waste and wastewater treatment plant and additional system controls. ${ }^{5}$

In 1996, Cia. Ingá Mercantil was one of the three largest zinc producers in Brazil, and its total capacity at that time represented 30\% of the Brazilian market. In February of 1996, the containment dam ruptured due to heavy rains and caused one of the largest environmental disasters in Rio de Janeiro's history by contaminating Sepetiba Bay with toxic metals. ${ }^{5,6}$ 
After the bankruptcy of Cia. Ingá Mercantil in 1998, $390,000 \mathrm{~m}^{3}$ of Class 1 tailings were abandoned and formed a pile that was approximately $45 \mathrm{~m}$ in height and composed mainly of metallurgical wastes rich in $\mathrm{Zn}$ and $\mathrm{Cd}$, as well as other toxic metals, such as $\mathrm{Pb}, \mathrm{As}, \mathrm{Cu}, \mathrm{Ni}, \mathrm{Co}, \mathrm{Fe}$ and Mn. ${ }^{1,5,6}$

In 2002, some of this material leaked into Sepetiba Bay; nothing was done to repair the dam, and a new leak occurred in 2003, which repeated the ecological disaster of 1996 when approximately $6,000 \mathrm{~m}^{2}$ of mangroves were buried in the waste. ${ }^{6}$

In 2011, the former Cia. Ingá Mercantil legacy was sold, and its area was decommissioned for the installation of a container terminal. Figures S1a and S1b (Supplementary Information (SI) section) show the area before and after the decommissioning, and the images show reduction of the waste pile and the remains of the existing industrial installations, as well as placement of a water pond between the waste and the mangroves. On the left side were a quarry and a coal storage yard. The decommissioning consisted of the removal of the waste pile and contaminated soil and deposition in an industrial landfill and the installation of a hydraulic barrier and an effluent treatment plant in order to treat the pumped groundwater. At the end of the decommissioning process, the Cia. Ingá Mercantil area was covered with a meterdeep layer of clay.

During 2001, the state environmental authority performed an extensive survey related to metal contents in the sediments of Sepetiba Bay, ${ }^{7}$ we used this study as a benchmark for the existing metal concentrations in 2016, especially $\mathrm{Zn}$ and $\mathrm{Cd}$, to evaluate whether their content in surface sediments had observably decreased and any significant redistribution was evident along the bay five years after the decommissioning.

The present hypothesis is that after the major and minor effluent releases and accidental waste dam ruptures ceased, which had occurred several times, the $\mathrm{Zn}$ and $\mathrm{Cd}$ concentrations in surface sediments decreased due to burial under less contaminated material and to dredging activity around the main navigation channel, the harbor and the ship terminals (Figure S2, SI section).

The reduction rate near Madeira Island, where the Cia. Ingá Mercantil was located, cannot be significant due to the existing mangrove area, which was heavily contaminated during the smelter existence and represents a latent $\mathrm{Zn}$ and $\mathrm{Cd}$ source to the bay. Potential submarine groundwater discharge, containing $\mathrm{Zn}$ and $\mathrm{Cd}$ from the tailing remains, was not considered due to the existence of the hydraulic barrier that decreases the height of the water table by its constant pumping.
The nearby Santa Cruz Industrial District, with two steelworks, one of them producing galvanized steel, and the "Casa da Moeda", which produces coins and medals, may represent additional metal releases to the bay.

Based on surface sediment samples and dated sediment cores, the spatial and temporal variation of $\mathrm{Zn}$ and $\mathrm{Cd}$ concentrations were studied, as well as additional metals, such as $\mathrm{Cr}$, related to the other metallurgical industries located close to the bay. Additionally, the effect of the surficial sediment contamination with $\mathrm{Zn}$ on organisms was tested based on transplanted oyster data covering a time period of 40 years.

\section{Experimental}

\section{Study area and sampling points}

Sepetiba Bay covers approximately $305 \mathrm{~km}^{2}$ and is limited to the northeast by the Serra do Mar, to the north by the Madureira Mountains, to the southeast by the Pedra Branca massif and to the south by the Restinga (sand ridge) of Marambaia (Figure S3, SI section). The bay is a body of saline and brackish water that connects to the Atlantic Ocean through two passages, including one located far to the west between a set of islands together with the end of a sand ridge and a secondary passage located in the eastern portion by the channel that empties into the Barra de Guaratiba, which gives the passage an almost elliptical configuration. The perimeter of the bay is approximately $130 \mathrm{~km}$.

To the south of the bay is the Marambaia Restinga, which is an immense sand dam that isolates Sepetiba Bay waters from the Atlantic Ocean, although it is only several meters above sea level. The Restinga is approximately $79 \mathrm{~km}^{2}$ and extends from Barra de Guaratiba in the east to the island of Marambaia in the west and is approximately $18 \mathrm{~km}$ from the continental border. ${ }^{7}$ The Guandú, Guarda and Piraquê Rivers as well as the São Francisco channel are the main freshwater contributors to the bay and its main siltation sources. Details on Sepetiba Bay hydrodynamics and geographical settings can be found in Cunha et al. ${ }^{8}$

Bottom sediments were taken using a Petersen grab, stored in acid-cleaned glass jars and kept cool by using a cooler and ice for transport to the laboratory, where samples were preserved in a refrigerator $\left(3{ }^{\circ} \mathrm{C}\right)$. Sampling stations are shown in Figure S3 (SI section) and follow the same grid established by the Rio de Janeiro State Environmental Agency (FEEMA), ${ }^{7}$ which includes 38 stations. The sediment cores were sampled using a 6.0 -cm-diameter gravity sediment corer (Uwitec Sampling Equipment, Austria) and a two-centimeter-high slicing apparatus. 
The sample collection was carried out between July and October 2016.

The surface sediment sampling point coordinates are shown in Table S1 in the SI section, and the corresponding sediment cores appear in Table S2.

\section{Metal determination}

Sediment samples were freeze-dried and ground with an agate mortar (RM-200, Retsh GmbH, Germany); then, the samples, which were collected in triplicate, were acid digested following the Environmental Protection Agency (EPA) 3050b method. ${ }^{9}$ The metal content was determined by applying the EPA $6020 \mathrm{~b}$ method ${ }^{10}$ with an inductively coupled plasma-mass spectrometer (ICP-MS) Agilent $7500 \mathrm{CX}$, and the following isotopes were measured: ${ }^{66} \mathrm{Zn}$, ${ }^{111} \mathrm{Cd},{ }^{53} \mathrm{Cr},{ }^{206} \mathrm{~Pb},{ }^{63} \mathrm{Cu}$ and ${ }^{60} \mathrm{Ni}$. Additionally, granulometry, organic carbon $(\mathrm{OC}), \delta\left({ }^{13} \mathrm{C}\right), \delta\left({ }^{15} \mathrm{~N}\right)$, acid volatile sulfides (AVS) and simultaneously extracted metals (SEM) were also determined and are described in Gonçalves et al. ${ }^{11}$

\section{Sediment dating}

Lead-210 was determined as described by Godoy et al. ${ }^{12}$ based on a three-gram dry sediment sample and double hot acid leaching, the first leaching with $40 \mathrm{~mL} \mathrm{HBr}$ at $0.50 \mathrm{~mol} \mathrm{~L}^{-1}$, followed by a second leaching with $40 \mathrm{~mL}$ $\mathrm{HBr}$ at $0.50 \mathrm{~mol} \mathrm{~L}^{-1}$ with $1 \mathrm{~g}$ hydroxylamine hydrochloride. Twenty milligrams of lead were added to determine the chemical yield, which followed lead separation by anionic ion exchange in bromidic media and elution with $\mathrm{HNO}_{3}$ at $1.0 \mathrm{~mol} \mathrm{~L}^{-1}$. Lead was precipitated as lead chromate, and ${ }^{210} \mathrm{Bi}$ was measured after 2-4 weeks of ingrowth, applying a low background gas flow proportional counter Prof Berthold LB-770.

Water content, zinc and cadmium profiles were applied as tools to choose which cores should be ${ }^{210} \mathrm{~Pb}$ dated. Those with a constant water content profile, with a large mixing zone or without $\mathrm{Zn}$ and $\mathrm{Cd}$ concentration peaks due to the 1996 waste dam rupture were not considered (cores T-3, T-8, T-20 and T-31). Cores T-13, T-18, T-19, T-26 and $\mathrm{T}-28$ were selected for dating, and the sedimentation rate was calculated by applying the constant rate-constant flux (CR-CF) and the constant rate of supply (CRS) models.

\section{Results and Discussion}

The metal concentrations, as well as the SEM and AVS values, are presented in Table S3 (SI section). In Table S4 (SI section) are presented the results obtained for the certified reference material (CRM) MESS-3, it is possible to observe that, with the $\mathrm{Cr}$ exception, all obtained recovery were higher than $90 \%$. As there are no Brazilian guidelines for sediment quality relative to metals, it is typical to apply the limits established by National Environmental Council (CONAMA) Resolution $454 / 2012,{ }^{13}$ which was devoted to dredged sediments and based on the Canadian Sediment Quality Guidelines for the Protection of Aquatic Life. Table 1 shows the descriptive statistics of the obtained results for $\mathrm{Cd}, \mathrm{Cr}, \mathrm{Cu}, \mathrm{Ni}, \mathrm{Pb}$ and $\mathrm{Zn}$, as well as a comparison to the CONAMA 454/2012 guidelines, ${ }^{13}$ for which level 1 corresponds to the Canadian threshold effect level (TEL) and level 2 to the probable effects level (PEL), and the results are similar to those published by Pellegatti et al. ${ }^{14}$ and Ribeiro et al. ${ }^{15}$ for the same region. According to the CONAMA 454/2012 resolution, ${ }^{13}$ elements such as $\mathrm{Cr}, \mathrm{Cu}, \mathrm{Ni}$ and $\mathrm{Zn}$ should have concentrations lower than level 2, and $\mathrm{Cd}$ and $\mathrm{Pb}$ concentrations should be below level 1. Based on the observed concentrations (Table 1), only Cd and Zn, which are the elements related to the former Cia. Ingá Mercantil smelter, exceed the sediment quality guidelines (SQG).

For comparison, the metal concentrations from other Brazilian bays under the influence of industries and harbors, such as Guanabara, Santos and Todos os Santos bays, are also presented. Guanabara Bay has $\mathrm{Cr}$ and $\mathrm{Zn}$ above

Table 1. Metal concentrations in Sepetiba Bay surface sediments, compared with those in other Brazilian industrial and harbor bays and the CONAMA 454/2012 sediment quality guidelines (values in bold are the applicable reference levels for each element)

\begin{tabular}{|c|c|c|c|c|c|c|c|}
\hline Local & $\mathrm{Cd} /\left(\mathrm{mg} \mathrm{kg}^{-1}\right)$ & $\mathrm{Cr} /\left(\mathrm{mg} \mathrm{kg}^{-1}\right)$ & $\mathrm{Cu} /\left(\mathrm{mg} \mathrm{kg}^{-1}\right)$ & $\mathrm{Ni} /\left(\mathrm{mg} \mathrm{kg}^{-1}\right)$ & $\mathrm{Pb} /\left(\mathrm{mg} \mathrm{kg}^{-1}\right)$ & $\mathrm{Zn} /\left(\mathrm{mg} \mathrm{kg}^{-1}\right)$ & Reference \\
\hline Sepetiba Bay & $1.6(0.4-4.6)$ & $79.7(1.5-145)$ & $8.4(0.3-24.6)$ & $9.9(0.8-15.5)$ & $13.9(2.2-25.7)$ & $295(29.7-1,116)$ & present work \\
\hline Guanabara Bay & $0.55(<0.10-2.9)$ & $112(26.4-507)$ & $69.1(12.5-134)$ & $23.1(10.6-48.0)$ & $71.1(33.2-145)$ & $313(100-791)$ & Monte et al. ${ }^{16}$ \\
\hline $\begin{array}{l}\text { Todos os Santos } \\
\text { Bay }\end{array}$ & $(0.003-5.56)$ & $(22-112)$ & $(0.16-489)$ & - & $(0.16-107)$ & $(0.44-332)$ & $\begin{array}{l}\text { CRA } 2004 \text { apud } \\
\text { Hatje and Barros }\end{array}$ \\
\hline Santos-São Vicente & $<0.38$ & $18.2(2.8-40.2)$ & $8.9(0.7-30.7)$ & $7.4(0.9-19.3)$ & $11.4(1.3-48.2)$ & $47.7(5.6-134)$ & Kim et al..$^{18}$ \\
\hline Ribeira Bay & $0.21(0.14-0.32)$ & $118(88.9-156)$ & $24.6(19.8-28.5)$ & $47(33.0-65.6)$ & $29.9(26.1-32.6)$ & $109(99-118)$ & Gomes et al. ${ }^{19}$ \\
\hline $\begin{array}{l}\text { CONAMA } \\
454 / 2012^{13}\end{array}$ & $\begin{array}{l}\text { level } \mathbf{1}=\mathbf{1 . 2} \\
\text { level } 2=7.2\end{array}$ & $\begin{array}{c}\text { level } 1=81 \\
\text { level } 2=\mathbf{3 7 0}\end{array}$ & $\begin{array}{c}\text { level } 1=34 \\
\text { level } \mathbf{2}=\mathbf{2 7 0}\end{array}$ & $\begin{array}{l}\text { level } 1=20.9 \\
\text { level } 2=\mathbf{5 1 . 6}\end{array}$ & $\begin{array}{l}\text { level } \mathbf{1}=\mathbf{4 6 . 7} \\
\text { level } 2=218\end{array}$ & $\begin{array}{l}\text { level } 1=150 \\
\text { level } \mathbf{2}=\mathbf{4 1 0}\end{array}$ & \\
\hline
\end{tabular}


the sediment quality guideline; $\mathrm{Cr}$ is related to a former chromium industry from Bayer, ${ }^{20}$ and $\mathrm{Zn}$ can be related to untreated sewage discharged into the bay. At Todos os Santos Bay, high metal concentrations for $\mathrm{Cd}, \mathrm{Cu}, \mathrm{Pb}$ and $\mathrm{Zn}$ are attributed to a formerly existing $\mathrm{Pb}$ smelter, ${ }^{17}$ and in the Santos-São Vicente estuarine system, the presence of metals such as $\mathrm{Pb}$ is attributed to releases from the Cubatão industrial zone. ${ }^{18}$ Ribeira Bay is a nonpolluted system and has been proposed as a reference area for Sepetiba Bay. ${ }^{19}$ In fact, the observed $\mathrm{Cd}$ and $\mathrm{Zn}$ concentrations are smaller than those verified at Sepetiba Bay. On the other hand, Ribeira Bay also represents an example of the need for a conscious use of sediment quality guidelines; due to its geology, high nickel concentrations above those in CONAMA 454/2012 have been verified. ${ }^{13}$

The $\Sigma$ SEM/AVS ratios are shown in Figure S4 (SI section), and the areas where the $\Sigma$ SEM reaches the highest values are those close to the former Cia. Ingá Mercantil location and to the Guandu River mouth, where the AVS also reaches high concentrations and the $\Sigma$ SEM/AVS ratio is below 1 ; similar findings were reported by Ribeiro et al..$^{15}$ Despite the elevated $\mathrm{Zn}$ and $\mathrm{Cd}$ concentrations, ratios lower than 1 indicate that these metals are present as sulfides and are not bioavailable. ${ }^{19,21,22}$

Figures 1a-1f shows metal distributions in the bay. Some elements are clearly correlated, such as $\mathrm{Cr}$ and $\mathrm{Ni}$, as well as $\mathrm{Cd}$ and $\mathrm{Zn}$. These correlations become more evident when parameters for total organic carbon (TOC), silt + clay (fine particles in percentage) and AVS are also included, as shown in Table 2.

The correlations involving $\mathrm{Cr}, \mathrm{Cu}, \mathrm{Ni}$ and $\mathrm{Pb}$ can be explained by their covariance with the (silt + clay) content, which has a distribution pattern similar to those observed for these elements (Figure S5, SI section). The areas with fine sediments are those in which high organic carbon content is also observed and, consequently, conditions are anoxic with high sulfide production. Zinc and cadmium, which primarily came from the Cia. Ingá Mercantil location, do not present statistically significant correlations with the granulometry.

The similarity of sampling points can be verified based on a cluster analysis, built based on the Ward linkage method, applying normalized $\mathrm{Z}$ values and squared Euclidean distances (Figure S6, SI section), in which four clusters are identified; the sampling points corresponding to each cluster are shown in Figure 2, with the green dots representing points with higher sand content and lower metals, sulfide and TOC, and the yellow to red colors indicating increases in these parameters. The red sampling points are those where the former Cia. Ingá Mercantil waste dam rupture had the highest impact.
Figure S7 (SI section) shows a box plot of metal concentrations according to the sampling point classifications. The sediment quality guideline (SQG) reference line is shown only for $\mathrm{Zn}$ and $\mathrm{Cd}$ but not for $\mathrm{Cr}$, $\mathrm{Cu}, \mathrm{Ni}$ and $\mathrm{Pb}$ because their concentrations are considerably lower and including the reference lines would distort the concentration scale. The $\mathrm{Zn}, \mathrm{Cd}, \mathrm{Cu}$ and $\mathrm{Pb}$ concentrations increase from green to red, whereas for $\mathrm{Cr}$ and $\mathrm{Ni}$, there was no statistically valid difference between the orange and red regions.

The temporal variations in $\mathrm{Zn}$ and $\mathrm{Cd}$ can be observed in Figures 3a-3b, which shows the percentage variations between the present results and those observed during the study by the Rio de Janeiro State Environmental Agency carried out in 2001 (equation 1). ${ }^{7}$ A decrease in the concentrations of up to $70 \%$ for $\mathrm{Zn}$ and $100 \%$ for $\mathrm{Cd}$ shows the positive impact that the Cia. Ingá Mercantil decommissioning had on the sediment quality. It must also be noted that the navigation channel and the ship terminal area are constantly dredged, which contributed to the reductions in the contamination levels. The hot spot near Madeira Island, where the observed reduction is the lowest, indicates that the contaminated mangrove area continues to be a latent source for $\mathrm{Cd}$ and $\mathrm{Zn}$ in the bay. The increase verified in the central area can be explained by the fact that this region is a sandy environment with low $\mathrm{Cd}$ and $\mathrm{Zn}$ concentrations (Figures 1a and 1f, respectively), and small variations may represent a large percentage difference between the two sampling periods. Additionally, some positive variations are observed along the shoreline, which represent input from the drainage basin and a poorly stabilized sewage system.

Percentage of variation $(\%)=\frac{\text { Conc }_{2001}-\text { Conc }_{2016}}{\text { Conc }_{2001}} \times 100$

Figure $3 \mathrm{c}$ shows that for elements not mainly related to the Cia. Ingá Mercantil location, such as $\mathrm{Pb}$, the area with an observed increase is more comprehensive and that areas with reductions in metal concentrations are more concentrated in the central part of the bay where the dredging activities are more intense.

The temporal variations in these metals were also evaluated based on the sediment cores. Given the described criteria, five cores from the nine sampled were selected for ${ }^{210} \mathrm{~Pb}$ dating. Figures $4 \mathrm{a}-4 \mathrm{~d}$ show the obtained ${ }^{210} \mathrm{~Pb}_{\text {excess }}$ profile with the mass depth for the sediment cores $\mathrm{T}-13, \mathrm{~T}-18, \mathrm{~T}-19$ and $\mathrm{T}-28$, those where the CR:CF model is applicable with mass sedimentation rates ranging from 0.349 to $0.261 \mathrm{~g} \mathrm{~cm}^{-2} \mathrm{y}^{-1}$ (mean 0.296 and SD $0.036 \mathrm{~g} \mathrm{~cm}^{-2} \mathrm{y}^{-1}$ ). However, at sampling station 26, 
(a)
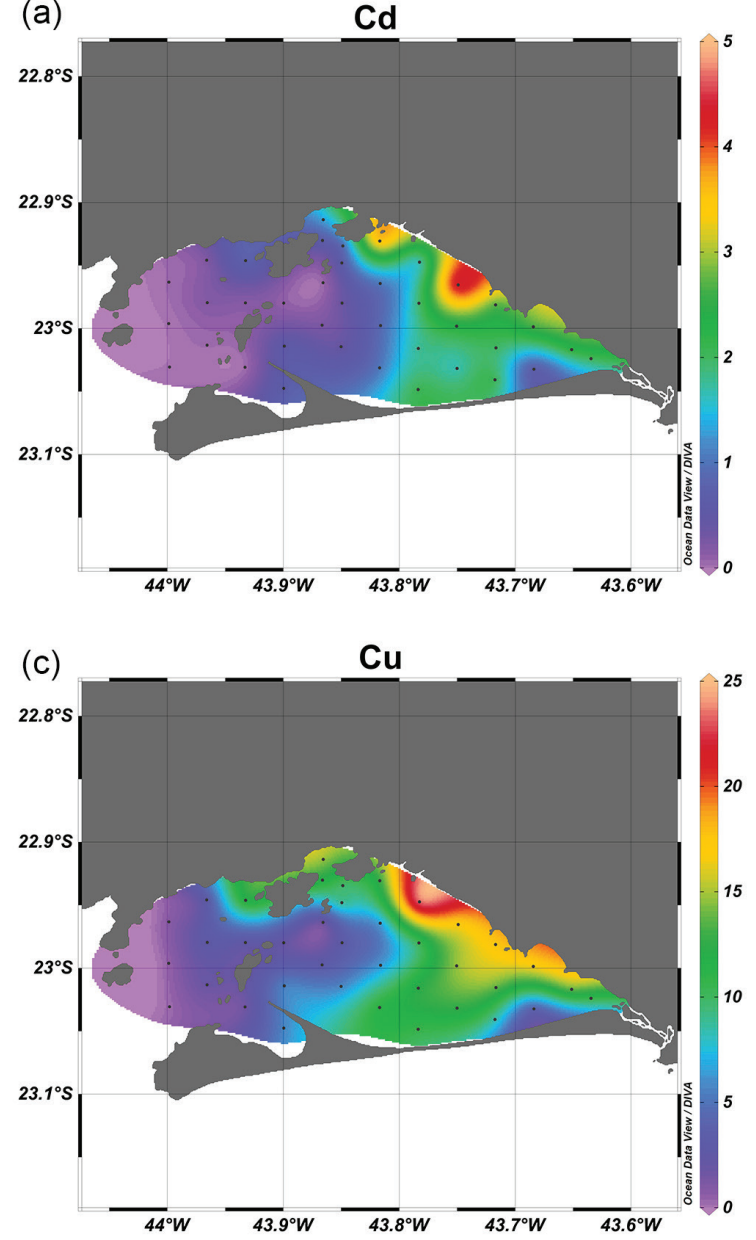

(e)

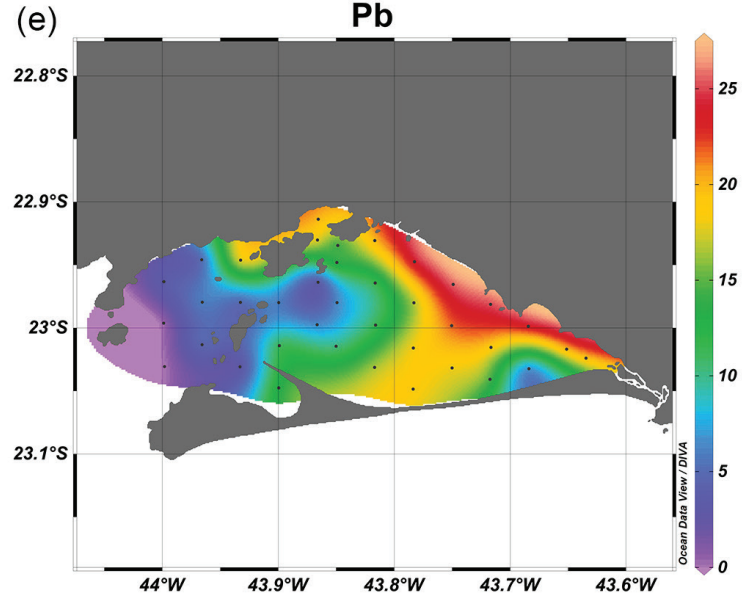

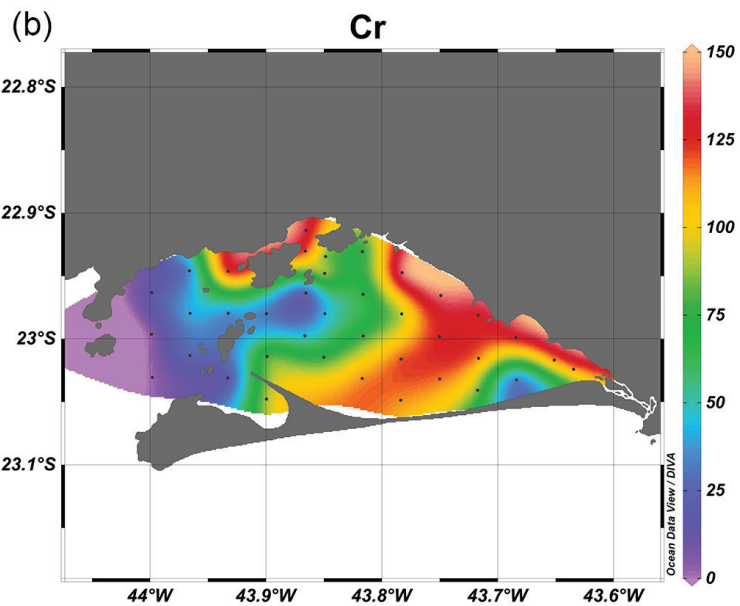
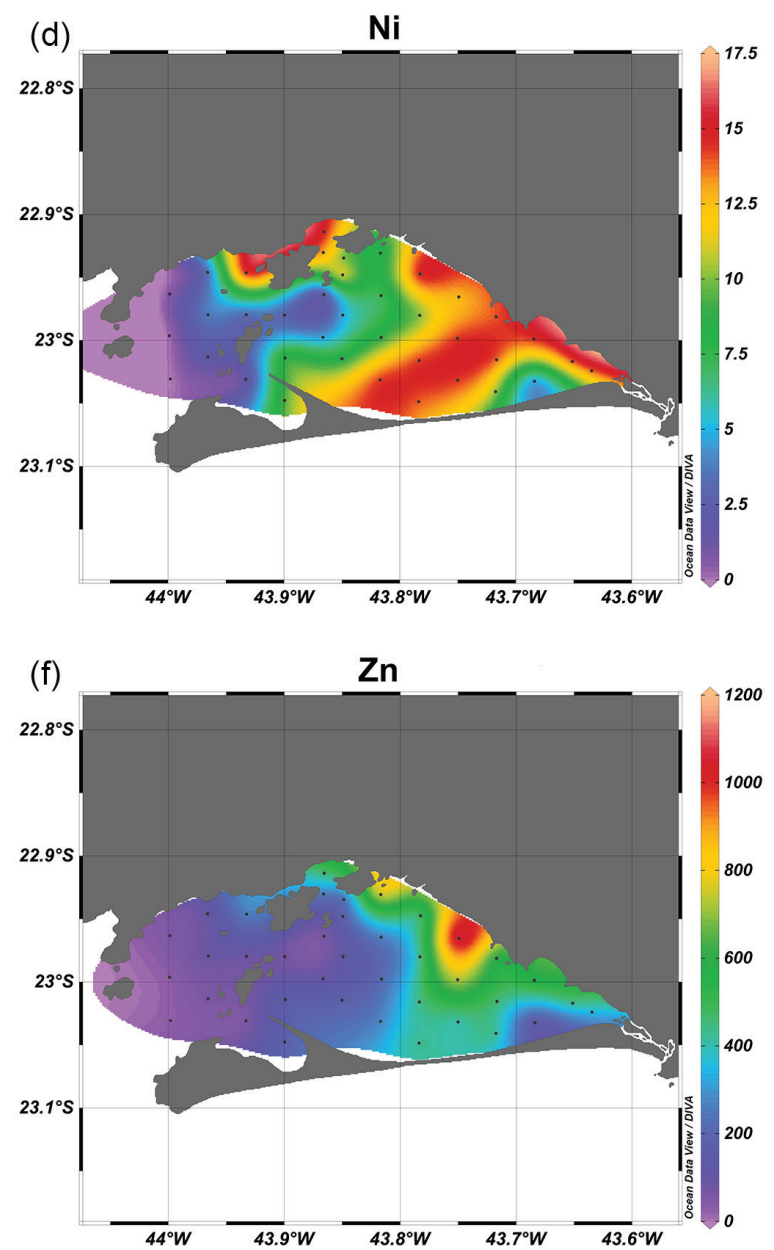

Figure 1. Metal distributions in Sepetiba Bay surface sediments in 2016 with the scale indicating mg kg ${ }^{-1}$. (a) $\mathrm{Cd}$; (b) $\mathrm{Cr}$; (c) $\mathrm{Cu}$; (d) $\mathrm{Ni}$; (e) $\mathrm{Pb}$; (f) $\mathrm{Zn}$.

the CRS model has to be applied, and two different sedimentation rates are observed with rapid changes in the early 1980s from $0.130 \mathrm{~g} \mathrm{~cm}^{-2} \mathrm{y}^{-1}$ to $0.255 \mathrm{~g} \mathrm{~cm}^{-2} \mathrm{y}^{-1}$ (Figure 5). This sampling station is located at the eastern end of the bay, which is an area influenced by the Guaratiba and Pedra de Guaratiba neighborhoods and an area that has experienced strong population augmentation following urban interventions during the early 1980s, such as new access roads and the installation of new industries in the Santa Cruz Industrial District.

Some publications related to ${ }^{210} \mathrm{~Pb}$ sedimentation rates in Sepetiba Bay can be found. ${ }^{19,23-25}$ However, only the work of Borges and Nittrouer ${ }^{24}$ involved cores sampled in the same region as the present work. From the seven 
Table 2. Pearson correlation coefficients with bold values indicating $95 \%$ probability

\begin{tabular}{|c|c|c|c|c|c|c|c|c|c|}
\hline & $\mathrm{Zn}$ & $\mathrm{Pb}$ & $\mathrm{Cu}$ & $\mathrm{Cd}$ & $\mathrm{Cr}$ & $\mathrm{Ni}$ & TOC & AVS & Fine \\
\hline $\mathrm{Zn}$ & 1 & & & & & & & & \\
\hline $\mathrm{Pb}$ & 0.847 & 1 & & & & & & & \\
\hline $\mathrm{Cu}$ & 0.793 & 0.957 & 1 & & & & & & \\
\hline $\mathrm{Cd}$ & 0.954 & 0.734 & 0.557 & 1 & & & & & \\
\hline $\mathrm{Cr}$ & 0.741 & 0.956 & 0.932 & 0.430 & 1 & & & & \\
\hline $\mathrm{Ni}$ & 0.670 & 0.913 & 0.881 & 0.313 & 0.978 & 1 & & & \\
\hline TOC & 0.589 & 0.742 & 0.707 & 0.560 & 0.718 & 0.690 & 1 & & \\
\hline AVS & 0.619 & 0.773 & 0.877 & 0.591 & 0.705 & 0.679 & 0.547 & 1 & \\
\hline Fine & 0.553 & 0.745 & 0.683 & 0.535 & 0.805 & 0.817 & 0.421 & 0.436 & 1 \\
\hline
\end{tabular}

TOC: total organic carbon; AVS: acid volatile sulfides.

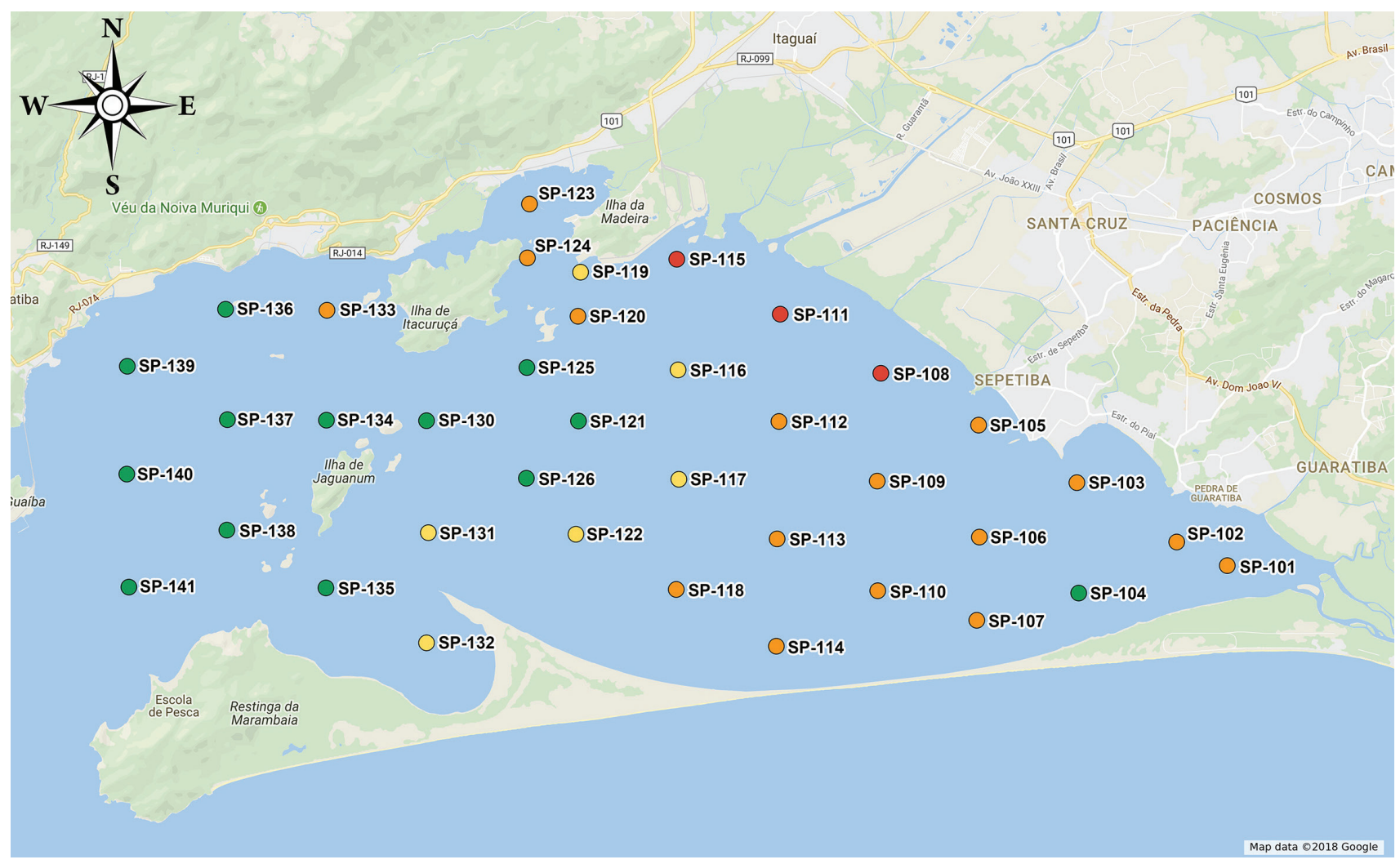

Figure 2. Sampling points grouped according to the cluster analysis.

cores sampled inside the bay, three of them were close to the actual sampling points, and the authors calculated the linear sedimentation rate without correction for compaction and data validation. Notwithstanding, the obtained rates, $0.4-1.2 \mathrm{~cm} \mathrm{y}^{-1}$, can be considered similar to the present values.

Table 3 presents the calculated age related to the $\mathrm{Zn}$ concentration peak. A large deviation is observed for core $\mathrm{T}-13$, which corresponds to the sediment core closest to the Guandu River and São Francisco River. The CRS model was tested for this core, presenting similar results as the
CR:CF model. However, considering a $95 \%$ confidence interval, all calculated ages agree with the expected age.

Core 19 was selected to exemplify the obtained metal profiles (Figures 6a-6f). Zinc and cadmium followed the described pattern once both were related to the Cia. Ingá Mercantil activities. The red bars in Figures $6 a$ and $6 b$ represent the sediment quality guideline (SQG) according the CONAMA resolution 454/2012. ${ }^{13}$ The SQG values for chromium, nickel, copper and lead are not included to prevent the figures from distortion because the observed concentrations are considerably lower than the reference 

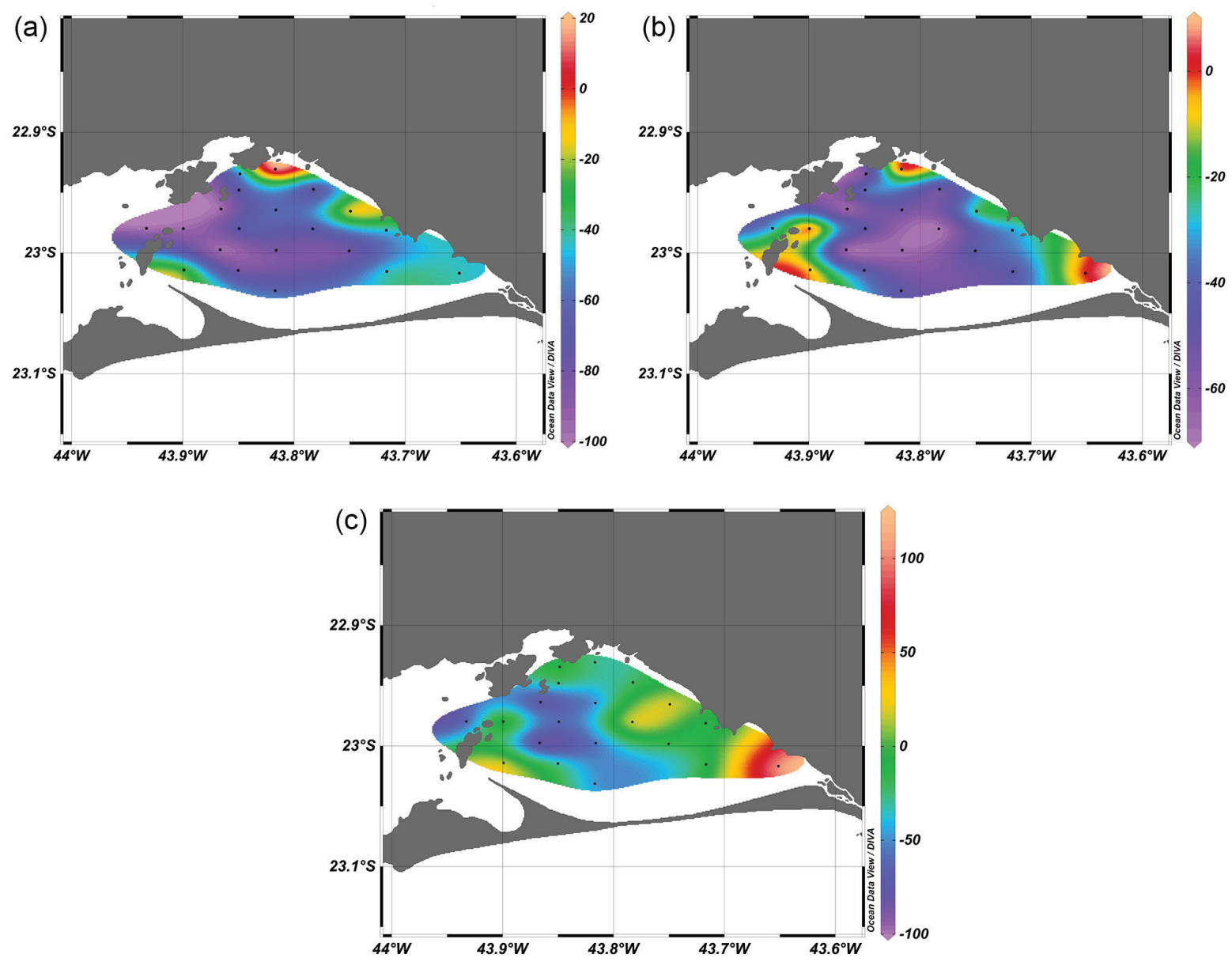

Figure 3. Temporal variations (\%) of $\mathrm{Cd}(\mathrm{a}), \mathrm{Zn}$ (b) and $\mathrm{Pb}$ (c) concentrations in surface sediments from Sepetiba Bay between 2001 and 2016.

values. Chromium, nickel, copper and lead present different profiles with two different peaks. The first peak at the end of 1950 may be related to the Paraíba do Sul River water diversion to the Guandu River, which increased the sediment load in Sepetiba Bay. ${ }^{26}$ The second peak could be a consequence of the "Casa da Moeda" installation in the Santa Cruz Industrial District in 1984. The "Casa da Moeda" produces Brazilian currency, including bills and coins, as well as medals such as those used for the 2016 Olympic Games in Brazil. After a plateau corresponding to the 2000-2010 period, a reduction is verified that is associated with the $90 \%$ water reuse policy started in 2014 at the "Casa da Moeda" plant.

Sepetiba Bay has been a place with intensive mariculture involving oysters, among others. Oyster (Crassostrea rhizophorae) seeds are collected from the rocky coasts around the bay and its islands and transplanted to oyster farms. As oysters are known to bioaccumulate zinc, they were chosen by the state environmental authority for biomonitoring, in particular due to the Cia. Ingá Mercantil presence. ${ }^{27}$

The data before 2007 were obtained from the literature..$^{28}$ The results between 2007 and 2017 are related to the environmental monitoring program developed by the local port authority, the results of which are available from the Rio de Janeiro state environmental agency by request. According to these reports, oyster seeds are placed into plastic cages, transplanted to the sampling points (Figure S8, SI section) and placed for one month at a water depth of one meter below the surface. After this time period, the oysters are removed, and their $\mathrm{Zn}$ and $\mathrm{Cd}$ concentrations are determined. The monitoring program is developed on a biannual basis.

Figure 7 shows the temporal variation in the $\mathrm{Zn}$ concentrations in sediments, based on sediment core 19 and in oysters. It is possible to observe that zinc concentrations in both sediments and oysters follow the same trend as the peak reflecting the 1996 dam rupture. The correlation between zinc in sediments and oysters in Sepetiba Bay was demonstrated by Rebelo et al. ${ }^{28}$ Similar findings were reported by Birch and Hogg, ${ }^{29}$ who observed a strong correlation between zinc in oyster tissue and in fine-fraction surficial sediments. It has taken approximately 20 years for the zinc content in oysters to reach the 2016 

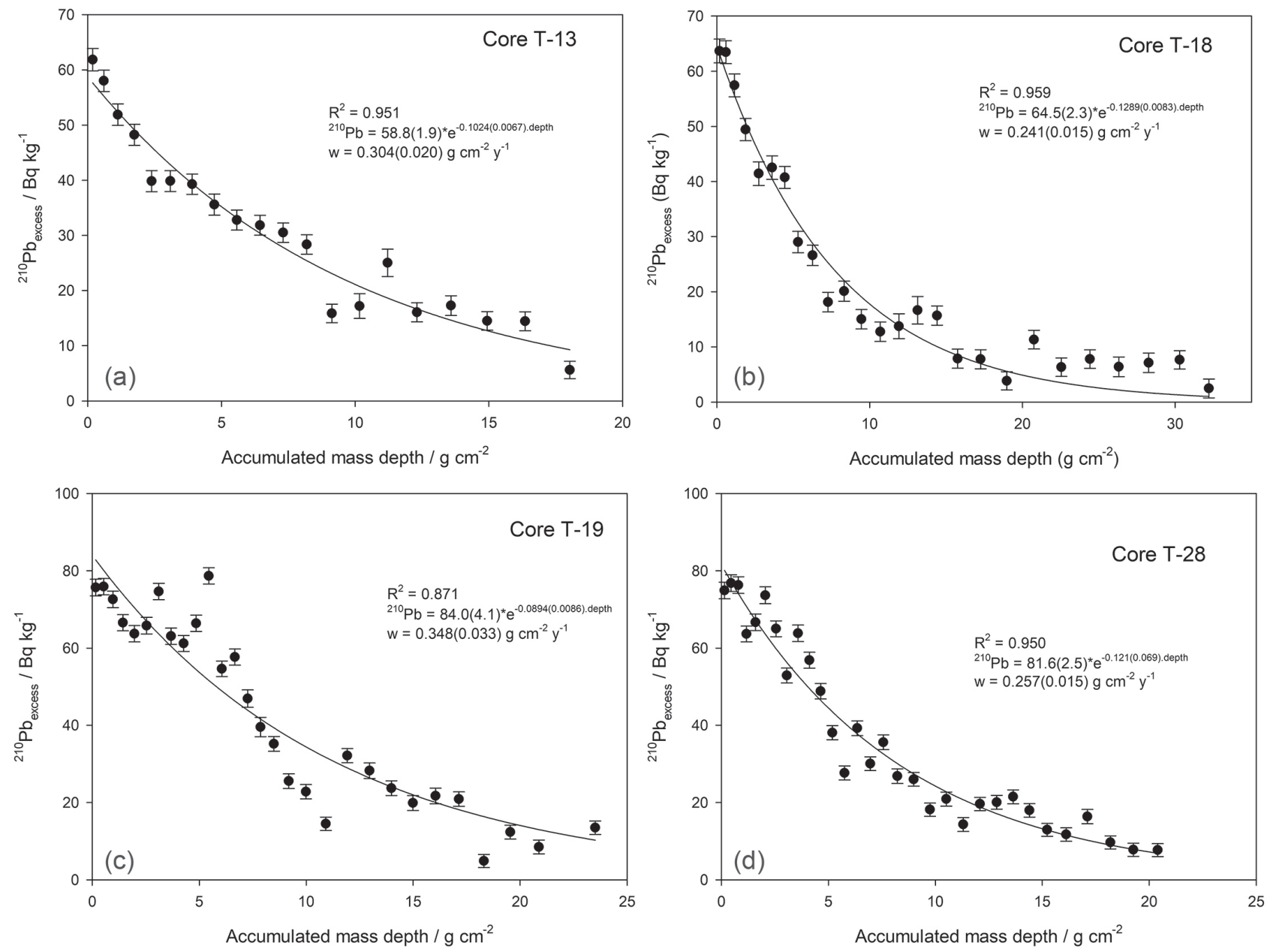

Figure 4. ${ }^{210} \mathrm{~Pb}_{\text {excess }}$ profile versus the accumulated mass depth for sediment cores (a) T-13; (b) T-18; (c) T-19 and (d) T-28.

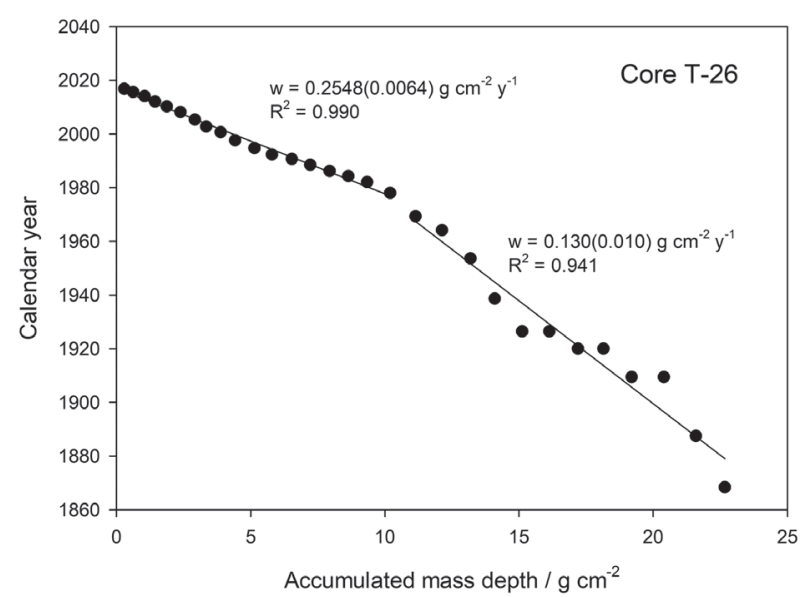

Figure 5. CRS model results for sediment core T-26.

and 2017 levels, $450 \mathrm{mg} \mathrm{kg}^{-1}$, which are even lower than those observed in the northern part of Rio de Janeiro state. ${ }^{30}$ Considering that the $\mathrm{Cd}$ concentration in oysters has decreased to $0.078 \mathrm{mg} \mathrm{kg}^{-1}$ during 2016 and 2017, it is possible to conclude that, based on these two elements, the oysters in Sepetiba Bay are again edible.
Table 3. Calculated age corresponding to the $\mathrm{Zn}$ concentration peak

\begin{tabular}{lc}
\hline Sediment core & Zn peak year (1 sigma uncertainty) \\
\hline T-13 & $1992(2)$ \\
T-18 & $1998(1)$ \\
T-19 & $1997(2)$ \\
T-26 & $2001(4)$ \\
T-28 & $1994(1)$ \\
\hline
\end{tabular}

\section{Conclusions}

The obtained results have shown that the decommissioning of the former Cia. Ingá Mercantil legacy had a positive impact on the sediment quality in Sepetiba Bay. However, the mangrove area directly affected by the waste dam rupture continues to be a latent source for $\mathrm{Zn}$ and $\mathrm{Cd}$ in the bay. The spatial variations in $\mathrm{Cr}, \mathrm{Cu}, \mathrm{Ni}$ and $\mathrm{Pb}$ are different from those observed for $\mathrm{Zn}$ and $\mathrm{Cd}$, are correlated with the (silt + clay) percentage and seem to be unaffected by the decommissioning, which suggests that other major sources for these metals in Sepetiba Bay 

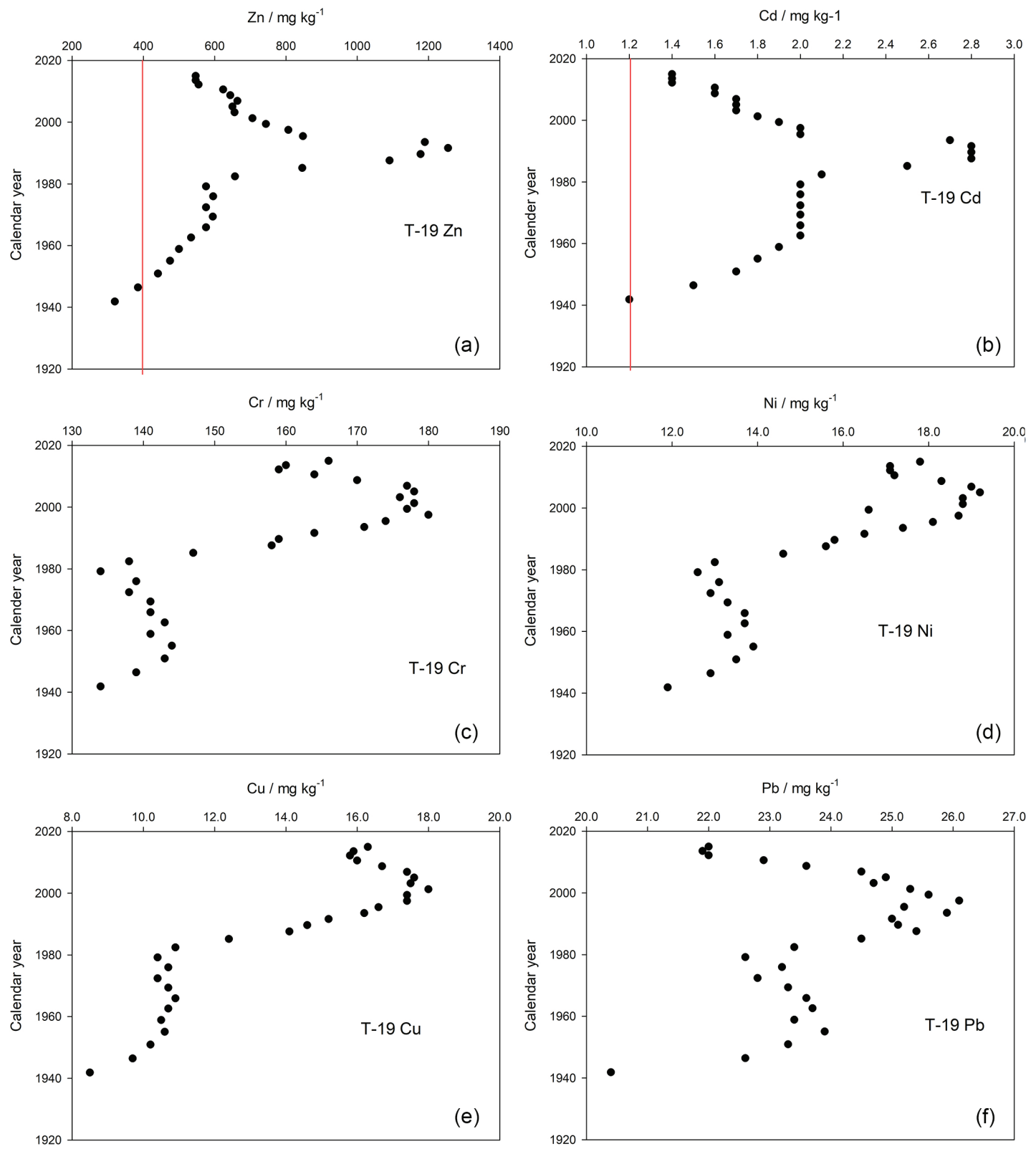

Figure 6. $\mathrm{Zn}(\mathrm{a}), \mathrm{Cd}(\mathrm{b}), \mathrm{Cr}(\mathrm{c}), \mathrm{Ni}$ (d), $\mathrm{Cu}$ (e) and $\mathrm{Pb}$ (f) depth profiles observed at sampling station $\mathrm{T}-19$ in which the red bars represent the CONAMA $454 / 2012$ levels for $\mathrm{Zn}$ and $\mathrm{Cd}$.

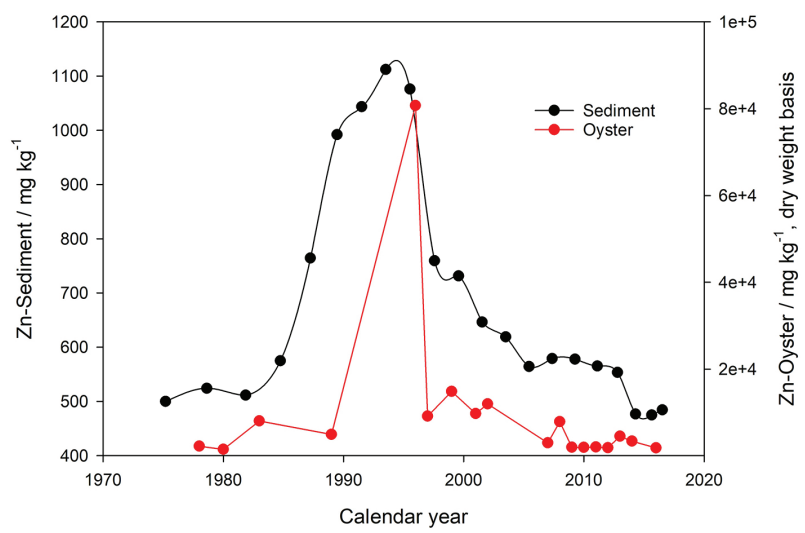

Figure 7. Temporal variation in $\mathrm{Zn}$ content in oysters and in sediments based on ${ }^{210} \mathrm{~Pb}$ dated sediment core 19 . are probably associated with fluvial inputs from materials eroded from the drainage basin, as suggested in previous studies.

In addition to the observed effect of the decommissioning, the observed $\mathrm{Zn}$ and $\mathrm{Cd}$ sediment depth profiles demonstrate that a further reduction in their concentrations seems to be due to burial of the most contaminated layer with less contaminated sediments. Despite the verified reductions in the $\mathrm{Zn}$ and $\mathrm{Cd}$ concentrations, there are still areas with values above the Brazilian sediment quality guidelines, particularly for $\mathrm{Cd}$, which means that the concentration is higher than that set by the Brazilian guidelines (CONAMA 454/2012). ${ }^{13}$ 
The $\Sigma$ SEM/AVS ratio is less than one across the entire bay, with the highest value equal to 0.4 , which indicates that the studied metals are present as sulfides and have low bioavailability, at least within the present hydrochemical environment of Sepetiba Bay. Conversely, this outcome should call attention to the continuing dredging activity within the bay, which may increase sediment oxidation and therefore sulfide dissolution, as well as the release of metals into the water column.

The decreases in the $\mathrm{Zn}$ and $\mathrm{Cd}$ concentrations in surficial sediments, associated with their low bioavailability, also result in decreasing concentrations in oysters, which similarly reached a maximum peak in 1996, following the major dam rupture. The observed $\mathrm{Zn}$ and $\mathrm{Cd}$ concentrations in oysters during 2016 and 2017, $450 \mathrm{mg} \mathrm{kg}^{-1}$ and $0.078 \mathrm{mg} \mathrm{kg}^{-1}$, respectively, returned to pre-1980 values and allow human consumption.

Five of nine sediment cores yielded datable cores, and the CR:CF model is applicable to four of them, with a mean mass sedimentation rate of $0.298(0.036) \mathrm{g} \mathrm{cm}^{-2} \mathrm{y}^{-1}$. The CRS model is applied to the T-26 core, showing a mass sedimentation rate of $0.130 \mathrm{~g} \mathrm{~cm}^{-2} \mathrm{y}^{-1}$ before 1980 and $0.255 \mathrm{~g} \mathrm{~cm}^{-2} \mathrm{y}^{-1}$ after, credited to the Santa Cruz industrial district development.

\section{Supplementary Information}

Supplementary data are available free of charge at http://jbcs.sbq.org.br as PDF file.

\section{Acknowledgments}

The authors are grateful to the PH-Mar employees for their help during the sediment sampling. The authors would like also to express their gratitude to the Instituto Estadual do Ambiente (INEA) allowing the access to the biomonitoring program data.

\section{References}

1. Molisani, M. M.; Marins, R. V.; Machado, W.; Paraquetti, H. H. M.; Bidone, E. D.; Lacerda, L. D.; Reg. Environ. Change 2004, 4, 17.

2. Barcellos, C.; Lacerda, L. D.; Environ. Monit. Assess. 1994, 29, 183.

3. Magalhães, V. F.; Pfeiffer, W. C.; J. Geochem. Explor. 1995, 52, 175.

4. Magalhães, V. F.; Carvalho, C. E. V.; Pfeifer, W. C.; Water, Air, Soil Pollut. 129, 83, 2001.

5. Bufoni, A. L.; Carvalho, M. S.; Pensar Contábil 2009, 11, 16.
6. Lacerda, L. D.; Molisani, M. M.; Mar. Pollut. Bull. 2006, 52, 974.

7. Fundação Estadual de Engenharia do Meio Ambiente (FEEMA); Baía de Sepetiba, Rios da Baixada da Baía de Sepetiba, Diagnóstico de Qualidade de Águas e Sedimentos; Fundação Ricardo Franco: Rio de Janeiro, Brazil, 2006.

8. Cunha, C. L. N.; Rosman, P. C. C.; Ferreira, A. P.; Monteiro, T. C. N.; Cont. Shelf Res. 2006, 26, 1940.

9. United States Environmental Protection Agency (EPA); Method 3050B: Acid Digestion of Sediments, Sludges, and Soils; available at https://www.epa.gov/hw-sw846/sw-846test-method-3050b-acid-digestion-sediments-sludges-and-soils, accessed on August 2019.

10. United States Environmental Protection Agency (EPA); Method 6020b: Inductively Coupled Plasma-Mass Spectrometry; available at https://www.epa.gov/hw-sw846/sw-846-testmethod-6020b-inductively-coupled-plasma-mass-spectrometry, accessed in August 2019.

11. Gonçalves, R. A.; Oliveira, D. F.; Ferreira, P. H. G.; Rezende, C. E.; Almeida, P.; Lacerda, L. D.; Godoy, J. M.; Mar. Pollut. Bull. 2018, 135, 1158.

12. Godoy, J. M.; Moreira, I.; Wanderley, W.; Simões Filho, F. F. L.; Mozeto, A. A.; Radiat. Prot. Dosim. 1998, 75, 111.

13. Conselho Nacional do Meio Ambiente; Estabelece as Diretrizes Gerais e os Procedimentos Referenciais para o Gerenciamento do Material a ser Dragado em Águas sob Jurisdição Nacional; Resolução 454 de 01 de novembro de 2012, Brazil. Available at http://www.mma.gov.br/port/conama/legiabre. cfm?codlegi=693, accessed in August 2019.

14. Pellegatti, F.; Figueiredo, A. M. G.; Wasserman, J. C.; Geostand. Newsl. 2001, 25, 307.

15. Ribeiro, A. P.; Figueiredo, A. M. G.; Santos, J. O.; Dantas, E.; Cotrin, M. E. B.; Figueira, R. C. L.; Silva Filho, E. V.; Wasserman, J. C.; Mar. Pollut. Bull. 2013, 68, 53.

16. Monte, C.; Cesar, R.; Rodrigues, A. P.; Siqueira, D.; Serrano, A.; Abreu, L.; Teixeira, M.; Vezzone, M.; Polivanov, H.; Castilhos, Z.; Campos, T.; Machado, G. G. M.; Souza, W. F.; Machado, W.; Environ. Sci. Pollut. Res. 2018, 25, 35596.

17. Centro de Recursos Ambientais; Diagnóstico da Concentração de Metais Pesados e Hidrocarbonetos de Petróleo nos Sedimentos e Biota da Baía de Todos os Santos; Consórcio BTS Hydros CH2MHILL, Governo do Estado da Bahia: Salvador, 2004 apud Hatje, V.; Barros, F.; Mar. Pollut. Bull. 2012, 64, 2603.

18. Kim, B. S. M.; Salaroli, A. B.; Ferreira, P. A. L.; Sartoretto, J. R.; Mahiques, M. M.; Figueira, R. C. L.; Mar. Pollut. Bull. 2016, 103, 333.

19. Gomes, F. C.; Godoy, J. M.; Godoy, M. L. D. P.; Carvalho, Z. L.; Lopes, R. T.; Sanchez-Cabeza, J. A.; Lacerda, L. D.; Wasserman, J. C.; Mar. Pollut. Bull. 2009, 59, 123.

20. Godoy, J. M.; Oliveira, A. V.; Almeida, A. C.; Godoy, M. L. D. 
P.; Moreira, I.; Wagener, A. R.; Figueiredo Jr., A. G.; J. Braz. Chem. Soc. 2012, 23, 1265.

21. Ankley, G. T.; di Toro, D. M.; Hansen, D. J.; Berry, W. J.; Environ. Toxicol. Chem. 1996, 15, 2056.

22. di Toro, D. M.; Zarba, C. S.; Hansen, D. J.; Berry, W. J.; Environ. Toxicol. Chem. 1991, 10, 1541.

23. Mozeto, A. A.; Umbuzeiro, G. A.; Jardim, W. F.; Métodos de Coleta, Análises Físico-químicas e Ensaios Biológicos e Ecotoxicológicos de Sedimentos de Água Doce; Cubo Multimídia \& Propaganda: São Carlos, Brazil, 2006.

24. Borges, H. V.; Nittrouer, C. A.; J. Sed. Environ. 2016, 90, DOI: 10.12957/jse.2016.21868.

25. Marques Jr., A. N.; Monna, F.; Silva Filho, E. V.; Fernex, F. F.; Simões Filho, F. F. L.; Mar. Pollut. Bull. 2006, 52, 532.
26. Patchineelam, S. M.; Sanders, C. J.; Smoak, J. M.; Zem, R. C.; Oliveira, G.; Patchineelam, S. R.; J. Braz. Chem. Soc. 2011, 22 , 120.

27. Molisani, M. M.; Kjerfve, B.; Lacerda, L. D.; J. Hydrol. 2006, $331,425$.

28. Rebelo, M. F.; Amaral, M. C. R.; Pfeiffer, W. C.; Mar. Pollut. Bull. 2003, 46, 1341.

29. Birch, G. F.; Hogg, T. D.; Environ. Pollut. 2011, 159, 108.

30. Ferreira, A. G.; Machado, A. L. S.; Zalmon, I. R.; Braz. J. Biol. 2005, 65, 67.

Submitted: July 15, 2019

Published online: September 27, 2019 